certification schemes for the improvement of cereal, herbage and vegetable seeds. The post of assistant director was created following the resignation of Mr. A. Sandison, who has been deputy director of the Institute during the past seven years.

\section{Institution of Electrical Engineers:}

New Honorary Members

THE Council of the Institution of Electrical Engineers has elected the following to honorary membership : Colonel B. H. Leeson, recently director of the British Electrical and Allied Manufacturers' Association, in recognition of his extensive contributions to the application of electrical science and engineering in the manufacture of electrical plant and equipment, to the development of co-operative effort within the electrical industry and to the training of electrical engineers, and of the services he has rendered to the Institution during nearly half a century; and Dr. Richard L. Hearn, for his notable contributions in the development of electricity generation and its supply for the benefit and use of mankind, particularly in Canada, and for the part he has played in international co-operation in this field. Dr. Hearn was elected under the provisions of the rule whereby the Council is empowered to elect, once in every three years, an additional honorary member who is not at the time of his election a member of any class of the Institution.

Faraday Medal

THE thirty-eighth award of the Faraday Medal of the Institution has been made to Sir George Thomson, president of the British Association, in recognition of his outstanding contribution to the advancement of electrical science, of the leadership in research which he has given to others in this field, and of his inspiring services to education in science and technology. This Medal is awarded not more frequently than once a year, either for notable scientific or industrial achievement in electrical engineering or for conspicuous service rendered to the advancement of electrical science, without restriction as regards nationality, country of residence, or membership of the Institution.

\section{Youth Services in Great Britain}

In the House of Commons on February 3, the Minister of Education, Sir David Eccles, announced that the Government accepted in principle all the main recommendations for Government action of the report of the Committee appointed in November 1958 under the chairmanship of Lady Albemarle to review the contribution which the youth service in England and Wales could make in assisting young people to play their part in the community. The necessary discussions between the Ministry of Education, the local education authorities and the voluntary youth organizations, with the view of taking precise decisions how to act on the Albemarle recommendations, will take place urgently. The Government has decided that deficiencies in voluntary and paid workers, in buildings and facilities for sport, in money and enthusiasm, must be made good, though everything cannot be done at once, and the will to succeed must come from the local areas at least as much as from the centre. The Government will finance by Exchequer grant most of the recommended expansion in training facilities from 700 to 1,300 full-time youth leaders by 1966 , and Sir David hopes an emergency training college will be open by January 1, 1961. He proposes to ask interested parties to examine with him the execution of the recommendation regarding salaries and opportunities for transfer to other careers. Grants for starting buildings by the local authorities and voluntary organizations in the next two years will be

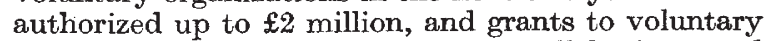
projects will be increased. Grants will be increased for headquarters expenditure of voluntary organizations for approved experiments in attracting young people not now using the youth service. Sir David said that, to begin with, he proposes himself to take the chair of the recommended Youth Service Development Council.

Sir David undertook to consider a suggestion that the House should discuss the Albemarle and the Crowther Reports together, and said that the Government proposes to accept the recommendation that the age-range of the youth service should be 14-20 years. A corresponding statement was made on the same day by the Minister for Science, Lord Hailsham, in the House of Lords.

\section{Gasification of Coal and Oil}

REPLYiNG to a question in the House of Commons on February 1, the Minister of Power, Mr. R. Wood, said the Gas Council is spending $£ 120,000$ this year on research into coal gasification, and the National Coal Board and the Central Electricity Generating Board $£ 680,000$ and $£ 130,000$, respectively, on coal utilization. The Gas Council is spending about $£ 230,000$ on research into the gasification of oil under a programme intended to contribute also to the improvement of the economics of coal gasification, and another $£ 240,000$ on research into problems of gas purification and the treatment of by-products.

\section{Trans-Pacific Telephone Calls}

THE United Kingdom Government has accepted the report of the Pacific Cable Conference, which was held in Sydney during September-October 1959, and in which Government representatives from Canada, Australia, New Zealand and the United Kingdom participated. Cable and Wireless, Ltd., will act for the United Kingdom Government in the construction, maintenance and financing of the cable. The total estimated cost is $£ 26 \cdot 3$ million, of which the United Kingdom share is $£ 8.3$ million. The cable will be more than 8,000 nautical miles long and will include more than three hundred under-sea amplifiers. In places, cable and amplifier will be laid to a depth of almost four miles. The project is to be undertaken by a joint Commonwealth Management Committee. The Committee will be under the leadership of $\mathrm{Mr}$. R. J. Halsey, director of research of the United Kingdom Post Office. A light-weight cable will be used with rigid repeaters developed in the United Kingdom and being used in Cantat, the cable between the United Kingdom and Canada. The Trans-Pacific Cable will have a capacity for at least eighty simultaneous conversations. Any one of the telephone circuits can be used to provide twenty-four telegraph channels.

\section{National Central Library}

THE forty-third annual report of the Executive Committee of the National Central Library, covering the year ended February 28, 1959, records that although the requests for loans continue to become more specialized and inaccessible in nature, the proportion of applications handled successfully continues to rise and is now 76 per cent (National Central 